PEMBELAJAR: Jurnal Ilmu Pendidikan, Keguruan, dan Pembelajaran

Volume 2 Nomor 2 Oktober 2018. Hal 116-124

e-ISSN: 2549-9114 dan p-ISSN: 2549-9203

(Received: Juli 2018; Reviewed: Agustus 2018; Published: Oktober 2018)

DOI: http://dx.doi.org/10.26858/pembelajar.v2i2.6362

\title{
Kemampuan Bercerita Anak Prasekolah (5-6 tahun)
}

\author{
Revina Rizqiyania ${ }^{a}$, Nur Azizah ${ }^{\mathrm{a}}$ \\ aPostgraduate Student of Early Childhood Education, Yogyakarta State University \\ ${ }^{\text {a } Y o g y a k a r t a}$ State University \\ Corespondensi Email: revina0208pasca2016@student.uny.ac.id,
}

\begin{abstract}
Abstrak: Tujuan penelitian ini yaitu untuk mengetahui pengetahuan tentang perkembangan bahasa anak prasekolah terutama dalam kemampuan bercerita. Penelitian ini melibatkan 60 anak yang terdiri dari 32 anak laki-laki dan 28 anak perempuan yang berkisar usia 5-6 tahun dan terdapat 4 guru. Metode yang digunakan yaitu eksperimen dengan desain control group pretest-posttet. Data deskriptive kualitatif didapat dari wawancara guru. Data kuantitatif didapat dari lembar observasi kemampuan bercerita. Anak-anak melakukan kegiatan bercerita menggunakan wordless picture book untuk kelompok eksperimen dan buku bergambar yang terdapat teksnya untuk kelompok kontrol. Penelitian ini menggungkapkan bahwa dengan wordless picture book lebih efektif untuk meningkatkan kemampuan bercerita pada anak prasekolah dibandingkan buku cerita pada umumnya. Anak-anak lebih mahir dalam pilihan kata dan gestur melalui gambar yang dilihat.
\end{abstract}

Kata kunci: wordless picture book, prasekolah, kemampuan bercerita

\begin{abstract}
The purpose of this study is to know the knowledge about the language development of preschoolers, especially in the ability to storytelling. The study involved 60 children consisting of 32 boys and 28 girls ranging in age from 5-6 years and there were 4 teachers. The method used is experiment with pretest-postest control group design. Qualitative descriptive data were obtained from teacher interviews. Quantitative data obtained from the observation sheet of storytelling ability. Children do story-telling activities using a wordless picture book for the experimental group and a picture book with text for the control group. This research reveals that with a wordless picture book is more effective to improve the ability to tell the story of preschoolers than the story books in general. Children are more adept at choice of words and gestures through the images they see.
\end{abstract}

Keywords: wordless picture book, preschool, ability to strorytelling

(C2018 -Pembelajar Universitas Negeri Makassar. Ini adalah artikel dengan akses terbuka dibawah licenci CC BY-NC-4.0 (https://creativecommons.org/licenses/by-nc/4.0/).

\section{PENDAHULUAN}

Pendidikan anak usia dini tidaklah lepas dari kegiatan bercerita. Anak-anak ditantang untuk mengenal budaya bercerita. Bercerita adalah menuturkan sesuatu yang mengisahkan tentang perbuatan atau sesuatu kejadian dan disampaikan secara lisan dengan tujuan membagikan pengalamannya. Bercerita memberikan contoh yang bagus dalam kurikulum berbasis bermain karena didalam bercerita berpusat pada anak, anak terlibat langsung dan terlibat secara bebas dalam aktivitas dan mampu mengarahkan sebagian besar prosesnya dan sangat bermanfaat pada anak (Wright, et al, 2007). Hal lain yang disampaikan bahwa mendongeng ialah alat yang ampuh untuk mempromosikan pemahaman diri kepada orang lain (Lenox: 2000). Temuan ini sejalan dengan hasil penelitian yang dilakukan oleh Setiati, Sunarto \& Setiawan (2013: 35) yang mengangkat pentingnya peran bercerita 
atau mendongeng jika terjadi komunikasi dengan anak-anak.

Bagaimanapun anak dapat bercerita jika anak didukung oleh guru atau orangtua. Selain itu dukungan fasilitas yang memadai seperti media yang digunakan penting untuk menunjang kegiatan bercerita. Salah satu media yang dapat memacu perkembangan anak dalam kemampuan bercerita ialah dengan media visual. Dengan menggunakan media visual bercerita dapat mempengaruhi beberapa faktor diantaranya faktor psikologis dan fisiologis. Faktor fisiologis dan psikologis dapat berdampak pada kedalaman persepsi visual dalam hal kategorisasi dan interpretasi makna (Xinyu Yu, 2012).

Melalui kegiatan bercerita anak mampu mengungkapkan bahasanya, mengungkapkan kemampuan berfikir, dapat berinteraksi dengan teman, membaca, dan menyimak. Menurut penelitian sebelumnya menggungkapkan bahwa banyak praktisi yang memiliki keterbatasan bercerita seperti subjektif, selektif, menyita waktu dan dangkal (Zhang, 2016). Penelitian lain mengungkapkan bahwa dengan bercerita anak dapat bercerita dan menceritakan kembali kisah-kisah atau pengalaman masa lalu dan mengaitkannya pada masa depan, bercerita juga dapat menghubungkan antar budaya, pendekatan pedagogi dan naratif (Southcott, 2015; Carr \& Lee, 2012).

Anak dapat menceritakan kembali isi cerita secara lisan sesuai dengan isi cerita jika si pencerita dalam menyampaikan isi cerita dapat mendorong dan memotivasi anak untuk bercerita. Menceritakan kembali cerita-cerita yang telah ada secara lisan memberi anak-anak sebuah bentuk latihan berbicara dan mendengar yang sederhana namun bersifat psiko-sosial yang jarang terjadi didalam kelas karena ini adalah asli dari pemikiran dan interaksi anak (Hibin, 2016). Anak bercerita dapat menggunakan media dapat pula menggunakan pengalaman-pengalamannya yang telah terjadi pada anak. Namun akan lebih baik jika untuk anak usia dini menggunakan media, karena dengan media dapat menjadi pendukung cerita dan membantu imajinasi anak untuk memahami isi cerita. Seperti penelitian yang telah dilakukan oleh Isbell (2002) bahwa dengan media ketika bercerita menunjukkan bahwa anak membangun kosa kata yang lebih kompleks, dan meningkatkan pemahaman saat sering terpapar cerita melalui gambar-gambar yang dilihat.
Pada nyatanya yang terjadi pada anak prasekolah usia 5-6 tahun masih terdapat anak yang belum mampu untuk bercerita dengan sendirinya. Bercerita bagi anak-anak ketika kegiatan dikelas tidak menarik, karena yang terjadi pada saat kegiatan pembelajaran tidak digunakan media yang dapat merangsang anak untuk bercerita dengan sendirinya. Selain itu ketika kegiatan bercerita tidak melibatkan anak, namun anak disuruh untuk menyimak dan mendengarkan cerita yang disampaikan oleh guru. Hal tersebut membuat anak asyik main sendiri, tidak mau mendengarkan guru ketika bercerita. Untuk itu penelitian ini akan melihat salah satu media yang dapat memberikan pengaruh yang positif untuk meningkatkan kemampuan bercerita.

Banyak media yang dapat membantu anak untuk bercerita, namun dengan media ini anakanak akan lebih mahir ketika bercerita tanpa menggunakan teks. Anak dapat bercerita dengan mengekspresikan diri, berimajinatif, dan melalui visual tersebut dapat meningkatkan kosa kata yang dimiliki oleh anak. Salah satu media visual yang dapat meningkatkan kemampuan bercerita pada anak yaitu dengan menggunakan media wordless picture book. Penelitian sebelumnya menjelaskan bahwa wordless picture book menghasilkan token kata, jenis kata dan ucapan yang lebih banyak, dan guru menunjukkan tingkat dukungan instruksional yang lebih tinggi, selain itu menunjukkan hubungan yang signifikan antara produksi bahasa anak-anak dan kualitas umpan balik guru selama pengajaran melek huruf, menunjukkan bahwa buku bergambar tanpa kata bisa meningkatkan bahasa anak-anak dengan meningkatkan dukungan instruksional (Leydi, Florencia, Carolina: 2017).

Penelitian lain yang dilakukan oleh Rebecca, Joseph, Liane \& Lowranc (2004) dengan menggunakan buku bergambar tanpa kata lebih efektif ketika anak membacakan cerita, selain itu memberikan pengalaman literatur yang kuat untuk mempengaruhi perkembangan bahasa lisan dan pemahaman cerita anak, terutama dalam pengembangan keaksaraan mereka. Anak dapat membuat cerita dengan kata-katanya sendiri dari gambar yang diberikan illustrator tersebut (Lysaker \& Miller, 2013). Menurut Zadra (2017) ketika membaca buku bergambar tanpa kata dan menceritakannya, anak tersebut merasakan di dalam cerita, belajar untuk berempati dan berpartisipasi dalam isi cerita. Membaca gambar ketika bercerita membangun 
interaksi mendalam dengan hubungan emosional pembaca.

Penelitian sebelumnya yang dijelaskan oleh Roux (2015) buku bergambar tidak memerlukan decoding kata-kata oleh pembaca, karena dapat dilihat dan diakses terutama bagi pembaca dengan melek huruf rendah. Pembacaan buku tanpa kata dapat menjadi konteks yang kaya untuk mengeksplorasi strategi pemahaman yang muncul bagi anak-anak (Lysaker, J \& Hopper, E., 2015). Dengan menggunakan buku bergambar tanpa kata memiliki karakteristik unik yang mengundang pembaca untuk terlibat secara dialogis dalam dunia cerita (Judith T., L \& Zaira A., A., 2016). Selama membaca buku tanpa kata, anak-anak mengatur pembuatan makna di seluruh mode ketika mereka memutuskan gambar mana yang harus diperhatikan, memilih di antara banyak makna, dan mewakili pembuatan makna berbasis gambar mereka dalam narasi lisan dengan cara linguistik (Lysaker \& Sedberry, 2015).

Buku bergambar tanpa kata juga dapat digunakan bagi melek huruf yang rendah, karena orang yang bercerita akan membuat kata-kata sendiri melalui gambar-gambar yang dilihat. Melek huruf adalah kemampuan untuk menciptakan konsep yang bermakna dengan mendengarkan, berbicara, membaca, menulis dan berpikir. Melibatkan manipulasi logis dari gagasan atau konsep dengan berbicara, mendengarkan dan berpikir yang berarti membaca dan menulis (Elizabeth \& Lory: 2017). Buku gambar tanpa kata membuat peluang untuk membangun gambaran visual gagasan dan konsep yang relevan yang melibatkan pemecahan masalah, penalaran, evaluasi, dan peningkatan kosa kata akademis di seluruh kurikulum (Elizabeth \& Lory: 2017). Anak-anak akan memulai berhipotesis, mengkonseptualisasikan, mempertanyakan, memprediksi, menyimpulkan, menganalisis, dan mengeksplorasi banyak jawaban berdasarkan interpretasi gambar visual.

\section{Wordless Picture Book}

Buku bergambar tanpa kata merupakan gabungan antara ilustrasi dan teks. Buku bergambar tanpa kata bertumpu pada interaksi antara ilustrasi dan teks, dan hasilnya dapat menguntungkan untuk anak-anak, dan juga mengarahkannya ke tingkat atau respons baru. Anak-anak dapat dengan mudah menerima jenis fantasi dari buku bergambar tanpa kata. Buku bergambar tanpa kata menghubungkan literasi visual, literasi budaya dan mendukung pengembangan keterampilan literasi (Jalongo et al: 2002).

Buku ini sangat berguna dalam merangsang pengembangan bahasa, karena anak dapat berperan aktif dalam bercerita tanpa terpaku teks. Membaca buku tanpa kata juga membutuhkan pemahaman ilustrasi yang spesifik. Dari ilustasi tersebut juga dapat meningkatkan anak yang kreatif. Karena di dalam cerita memiliki tindakan dan urutan yang jelas sehingga anak tidak akan bingung dan bosan ketika bercerita. Buku tanpa kata memberikan kompleksitas dan detail, serta kontinuitas dan konsistensi, setiap halaman ganda kompleks terbagi penuh dengan detail (Lukens: 2003). Buku bergambar tanpa kata dapat memberikan pengalaman literatur yang kuat untuk memengaruhi perkembangan bahasa lisan dan pemahaman cerita anak, terutama dalam pengembangan keaksaraan mereka (Rebecca, Joseph, Liane \& Lowranc: 2004).

Anak yang akan bercerita membuat katakata sendiri melalui gambar yang dilihat. Wordless picture book digunakan sebagai penilaian pengembangan keaksaraan (Judith T. Lysaker: 2006). Pemahaman seperti itu mencakup pengetahuan tentang struktur cerita, pengetahuan tentang ciri prosodi cerita, sifat bahasa tertulis, dan proses pemahaman. Penelitian lain juga telah menunjukkan bahwa kegiatan dengan menggunakan buku bergambar tanpa kata meningkatkan bahasa dan keterampilan melek huruf, termasuk kosa kata, keterampilan narasi lisan dan pemahaman anakanak prasekolah (Dickinson, Griffith, Michnick, \& Hirsh-Pasek, 2012; Zucker et al., 2013).

Pendapat lain menurut Jalongo et al (2002: 167) menjelaskan buku gambar tanpa kata menghubungkan literasi visual, melek budaya dan melek huruf melalui gambar cetak, yang mendukung pengembangan keterampilan membaca anak. Buku gambar tanpa kata bisa membantu instruksional dukungan, yang pada gilirannya, dapat mempengaruhi bahasa anakanak secara positif. Selain itu, buku bergambar tanpa kata bisa menarik minat lebih besar atau lebih banyak pertanyaan dari anak-anak (Leydi, Florencia, \& Carolina, 2017). Buku bergambar tanpa kata memiliki karakteristik sendiri dari buku yang lainnya, karena buku bergambar tanpa kata dimana teks dan ilustrasi 
digabungkan untuk membangun makna keseluruhan dari buku (Torr, 2004).

Buku cerita

Buku cerita merupakan buku pendidikan yang digunakan untuk menunjang kegiatan pembelajaran. Buku anak yang baik, apapun sifatnya, harus membawa kedunia anak (Winch \& Saxby, 1987). Buku memiliki empat sifat pokok, diantaranya 1) berisi informasi, 2) informasi ditampilkan dalam bentuk cetakan, 3) media yang digunakan adalah kertas, 4) lembaran kertas dijilid dalam bentuk satu kesatuan (Sitepu, 2015).

Manfaat Wordless Picture Books

Lysaker \& Miller (2013: 154) menjelaskan bahwa anak dapat membuat cerita dengan menggunakan kata-katanya sendiri dan gambargambar yang diberikan illustrator pada buku bergambar tanpa kata tersebut. Buku bergambar tanpa kata memberikan pengalaman literatur yang kuat untuk memengaruhi perkembangan bahasa lisan dan pemahaman cerita anak, terutama dalam pengembangan keaksaraan (Rebecca et al: 2004). Banyak manfaat yang dapat digunakan pada buku bergambar tanpa kata, diantaranya anak dapat berimajinasi, berfantasi membuat kata-kata untuk bercerita melalui gambar yang anak lihat. Manfaat wordless picture books juga untuk mendorong pengamatan dunia di sekitar (Mitchell: 2003).

\section{METODE}

Jenis penelitian pada penelitian ini yaitu menggunakan eksperimen kontrol group pretestpostest desain. Desain eksperimen melibatkan 30 anak kelompok eksperimen dan 30 anak kelompok kontrol dengan guru yang berbedabeda dari kelompok kontrol dan kelompok eksperimen. Guru diwawancara sebelum dan sesudah anak menggunakan wordless picture book dan buku cerita hal ini dilakukan untuk mendapatkan informasi mengenai kegiatan pembelajaran baik kelompok kontrol dan kelompok eksperimen. Teknik analisis descriptive-kualitative digunakan untuk hasil wawancara. Data kuantitatif akan digunakan desain eksperimen pre-experimental designs dengan control group pretest-posttest design. Analisis yang digunakan pada penelitian ini yaitu dengan menggunakan uji T-test, melihat perbedaan antara kelompok kontrol dengan kelompok eksperimen.

\section{Partisipan \\ Anak}

Sebanyak 60 anak dalam penelitian ini (32 anak laki-laki dan 28 anak perempuan). usia anak-anak berkisar 5-6 tahun, karena dalam penelitian ini hanya terfokus dengan anak-anak prasekolah yang berusia berkisar 5-6 tahun. Setiap harinya baik kelompok eksperimen dan kelompok kontrol anak-anak diacak untuk bergantian bercerita dengan buku bergambar tanpa kata untuk kelompok eksperimen dan buku bergambar dengan teks untuk kelompok kontrol. Setiap anak memiliki perbedaan dalam bercerita dengan buku bergambar tanpa kata.

\section{Prosedur}

Pada sesi ini eksperimen yang digunakan yaitu dengan menggunakan buku bergambar tanpa kata dan buku cerita yang terdapat teks. Dari kedua kelompok tersebut dinilai peningkatanya, apakah dengan menggunakan buku bergambar tanpa kata efektif untuk meningkatkan kemampuan bercerita anak atau dengan buku bergambar yang terdapat teksnya. Penelitian ini lebih fokus kepada anak prasekolah usia 5-6 tahun.

Prosedur penelitian ini yaitu digunakan untuk melihat keefektifan dari buku bergambar tanpa kata. Anak-anak diminta untuk bergantian bercerita dengan buku tersebut, dan berlanjut kehari selanjutnya jika belum selesai pada hari itu. Sebelum anak bercerita dari halaman awal hingga akhir, terlebih dahulu guru membacakan pengantar cerita kepada anak supaya anak akan lebih jelas cerita apa yang disampaikan setiap gambar pada halaman. Begitu juga dengan menggunakan buku bergambar yang terdapat teksnya. Anak diacak dan secara bergantian untuk bercerita dengan sendirinya pada setiap halamannya.

\section{HASIL DAN PEMBAHASAN}

\subsection{Hasil descriptive-kualitative}

Hasil yang didapat dari wawancara kepada guru, guru setuju bahwa pembelajaran dengan menggunakan buku bergambar tanpa kata menyenangkan untuk anak dan memotivasi anak untuk bercerita, karena buku tersebut tanpa teks yang membuat anak-anak dapat berimajinasi dengan sendirinya. Selain itu guru juga mengatakan menambah kosa kata melalui gambar-gambar yang dilihat. Antusiasme anak terhadap buku bergambar tanpa kata ketika 
bercerita menggunakan buku bergambar tanpa kata juga sangat terlihat. Anak dengan senang bercerita menggunakan buku tersebut. Anakanak bercerita dengan kata-katanya sendiri, dan merangang anak untuk berimajinasi dengan sendirinya melalui gambar-gambar yang dilihat.

Guru juga mengatakan dengan buku cerita seperti biasanya juga bagus untuk anak-anak, namun anak-anak tidak bisa menghayati cerita pada gambar yang ada, karena anak terpaku teks. Selain itu kurang adanya interaksi yang panjang antara guru dan anak, anak asyik sendiri membaca tanpa sadar bahwa ada yang mendengarkan ketika ia bercerita. Maka dari itu akan lebih baik menggunakan buku bergambar tanpa kata supaya indikator yang diinginkan tercapai. Seperti penelitian yang dilakukan Leydi, Florencia, Carolina (2017) guru menunjukkan tingkat dukungan instruksional yang lebih tinggi, selain itu menunjukkan hubungan yang signifikan antara produksi bahasa anak-anak dan kualitas umpan balik guru selama pengajaran melek huruf, menunjukkan

Tabel 1. Hasil kemampuan bercerita dengan buku cerita bahwa buku bergambar tanpa kata bisa meningkatkan bahasa anak-anak dengan meningkatkan dukungan instruksional dibandingkan dengan buku-buku biasanya.

\section{Hasil kuantitative}

Storybook

Hasil menggunakan buku bergambar yang terdapat teks menunjukan antara pretest dan postest eksperimen rata-rata yang didapatkan meningkat dari 16,97 menjadi 20,93. Namun dapat dilihat pada Tabel.1. Kegiatan bercerita menggunakan buku bergambar terdapat teks belum signifikan terhadap kemampuan becerita pada anak terutama dalam pilihan kata, dan mimik baik ketika bercerita anak tidak memiliki kata yang bervariasi dan anak belum dapat mengekspresikan dirinya ketika bercerita. Hasil hipotesis yang didapat yaitu $0,00<0,05$.

\begin{tabular}{lcccl}
\hline \multicolumn{5}{c}{ Paired Differences } \\
\hline & Mean & Std. Deviation & $\begin{array}{l}\text { Std. Error } \\
\text { Mean }\end{array}$ \\
\hline Pair 1 & pretest - postest & $-4,267$ & 2,638 &, 482 \\
\hline
\end{tabular}

95\% Confidence Interval of the Difference

\begin{tabular}{ccccc} 
Lower & Upper & $\mathrm{t}$ & $\mathrm{df}$ & $\begin{array}{l}\text { Sig. (2- } \\
\text { tailed) }\end{array}$ \\
\hline$-5,252$ & $-3,281$ & $-8,858$ & 29 &, 000
\end{tabular}

Wordless picture book

Hasil yang didapat pada kelompok eksperimen mengalami peningkatan yang signifikan dalam kemampuan bercerita pada anak dibandingkan kelompok kontrol. Pembelajaran yang digunakan oleh kelompok eksperimen menggunakan buku bergambar tanpa kata mendapatkan rata-rata pretest 18,93 dan ratarata posttest mendapatkan 24,87. Hal ini menunjukan bahwa dengan buku bergambar tanpa kata efektif untuk meningkatkan kemampuan bercerita. Dapat dilihat juga pada tabel menunjukkan bahwa sig < dari 0,005, yang berarti ada pengaruh yang signifikan dalam pembelajaran menggunakan buku bergambar tanpa kata terhadap kemampuan bercerita pada anak prasekolah usia 5-6 tahun. 
Tabel 2. Hasil kemampuan bercerita dengan wordless picture book

\begin{tabular}{ccccl}
\hline \multicolumn{4}{c}{ Paired Differences } \\
\hline & Mean & $\begin{array}{c}\text { Std. } \\
\text { Deviat } \\
\text { ion }\end{array}$ & $\begin{array}{l}\text { Std. Error } \\
\text { Mean }\end{array}$ \\
\hline Pair 1 & $\begin{array}{c}\text { pretest - } \\
\text { postest }\end{array}$ & $-5,933$ & 3,571 &, 652 \\
\hline
\end{tabular}

95\% Confidence

Interval of the

Difference

\begin{tabular}{ccccl} 
Lower & Upper & $\mathrm{t}$ & $\mathrm{df}$ & $\begin{array}{l}\text { Sig. }(2- \\
\text { tailed) }\end{array}$ \\
\hline$-7,267$ & $-4,600$ & $-9,100$ & 29 &, 000
\end{tabular}

Berikut gambar 1 hasil pretest-postest baik kelompok kontrol maupun kelompok eksperimen.

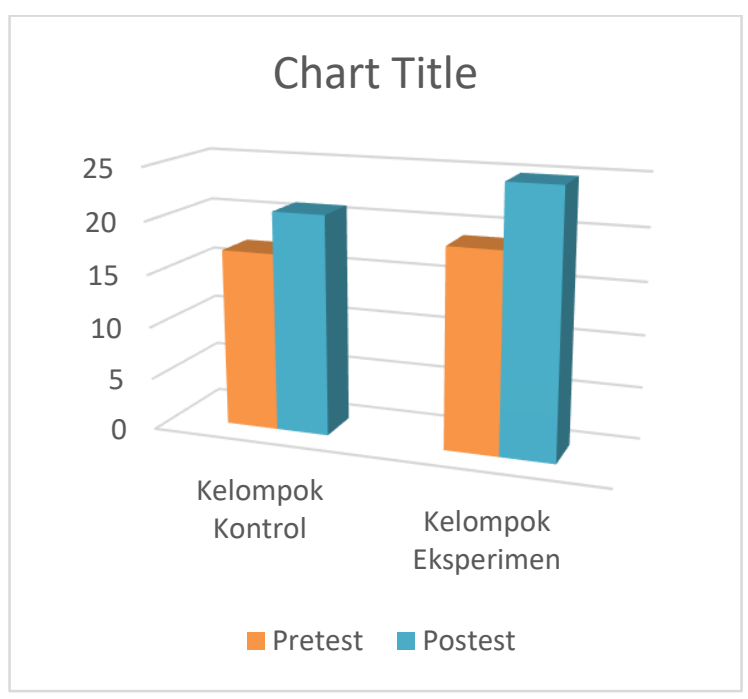

\subsection{Pembahasan}

Tujuan penelitian ini yaitu untuk melihat keefektifan buku bergambar tanpa kata yang digunakan ketika kegiatan bercerita. Kelompok kontrol pada penelitian ini yaitu untuk menggunakan buku cerita. Hasil analisis diketahui bahwa buku bergambar tanpa kata efektif untuk meningkatkan kemampuan bererita pada anak kelompok usia 5-6 tahun. Hal ini dibuktikan ketika anak bercerita dengan buku tapa kata lebih mahir dalam berimajinasi dan membuat kata-kata dengan sendirinya. Pada setiap anak juga saling berbeda ketika bercerita sesuai dengan gagasan yang anak sampaikan. Seperti penelitian sebelumnya menjelaskan bahwa buku tanpa kata bisa digunakan sebagai alat untuk memahami pembacaan yang muncul dari perspektif diri (Xinyu Yu: 2012). Penelitian Tain oleh Judith T. Lysaker (2006) menunjukkan bahwa kemampuan menjaga diri anak dapat mengikuti sebuah rangkaian dalam kaitannya dengan membaca tanpa kata-kata. Anak-anak dapat menunjukkan kemampuan yang berbeda dalam konteks bahasa dan keaksaraan yang berbeda, seperti anak-anak dapat menemukan karakter imajiner pada usia yang sangat muda.

Penelitian yang dilakukan kepada 30 anak ketika membaca buku tanpa kata. Menunjukkan bahwa lebih efektif untuk anak-anak ketika membacakan cerita melalui gambar-gambar yang dilihat pada buku bergambar tersebut. Anak-anak menggambarkan lebih mahir dalam membuat kata-kata dan berimajinasi dengan sendiri ketika bercerita dengan buku bergambar tanpa kata. Selain itu anak-anak juga mempunyai kosa kata yang lebih banyak dan berbeda satu sama lainnya. Tingkat dukungan guru juga lebih tinggi ketika pembelajaran menggunakan buku bergambar tanpa kata, guru lebih setuju menggunkan media tersebut. Karena, buku ini membuat anak-anak percaya diri ketika bercerita tanpa terpaku teks.

Penelitian yang dilakukan dikelompok kontrol yang menggunakan buku bergambar yang terdapat teksnya. Anak-anak ketika bercerita dengan buku bergambar yang terdapat teksnya anak terpaku dengan teks tersebut. Sehingga anak tidak menikmati gambar-gambar yang ada pada buku, anak tidak menghayati kedalam cerita yang sedang anak ceritakan. Anak yang dapat membaca dengan santainya membaca teks yang ada pada gambar namun asyik sendiri membaca tanpa memperhatikan teman didepan, namun berbeda dengan anak yang belum dapat membaca. Anak-anak yang belum dapat membaca sangat bingung ketika disuruh maju kedepan oleh guru untuk bercerita, sebagian anak juga hanya diam saja. Anak juga mengatakan bahwa dia tidak bisa bercerita karena belum bisa membaca. Penelitian ditemukan bahwa anak-anak lebih banyak merujuk pada karakteristik bergambar dan terlibat dalam percakapan yang lebih lama 
terkait dengan ilustrasi buku bergambar tanpa kata dibandingkan dengan buku yang terdapat teksnya (Tower, 2002).

Buku bergambar tanpa kata memiliki ilustrasi yang penuh warna, setiap halaman memiliki warna-warna yang menarik dan memotivasi anak untuk bercerita dengan sendiri. Ilustrasi menarik perhatian anak-anak dan membuat isi buku lebih konkret dan bermakna (Greenhoot \& Semb, 2008). Sejalan dengan ini, Kami menemukan bahwa ketika guru membaca buku bergambar tanpa kata-kata, mereka cenderung membangun cerita bersama dengan anak-anak (Leydi, Florencia, Carolina, 2017). Terlepas dari tidak adanya teks verbal, kita berurusan dengan buku-buku yang masih menuliskan proses membaca yang mudah dikenali, sehingga membutuhkan pembaca yang penuh perhatian, perseptif dan aktif yang bersedia ikut serta dalam permainan membaca (Ramos \& Ramos: 2011). Peneliti lain telah menunjukkan bahwa Anak-anak berusia tiga sampai lima tahun dicirikan oleh ketergantungan pada persepsi mereka karena mereka melihat apa yang tampak pada mereka melalui gambargambar tersebut (Xinyu Yu: 2012). Hal ini jelas bahwa buku bergambar tanpa kata efektif untuk anak dalam pengembangan bahasa terutama bercerita pada anak prasekolah usia 5-6 tahun.

\section{SIMPULAN DAN SARAN}

Berdasarkan hasil perhitungan yang telah dilakukan menunjukkan bahwa dengan menggunakan wordless picture book dapat memberikan pengaruh yang positif terhadap pembelajaran bercerita kepada anak prasekolah. Hal ini juga dibuktikan ketika pembelajaran berlangsung anak-anak lebih aktif dalaam bercerita, anak-anak memiliki kata-kata yang bervariasi ketika bercerita, memiliki pembendaharaan kata yang luas, mengetahui nama-nama tempat, benda dan hewan yang ada digambar, bercerita dengan mengaitkan pengalaman, memiliki gestur seperti sikap yang santai ketika bercerita, pandangan menuju lawan bicara, mengekspresikan diri ketika bercerita.

Wordless picture book juga memberikan interaksi yang panjang antara guru, anak dan teman sebanyanya. Anak-anak lebih senang ketika pembelajaran dengan menggunakan media tersebut, sedangkan pada kelompok kontrol menunjukkan bahwa anak-anak terpaku oleh teks tanpa menghayati isi cerita pada cerita tersebut. Anak-anak juga yang belum mahir dalam membaca mengalami kesulitan ketika harus bercerita, perlu dibantu oleh guru. Hal ini yang membuat anak tak percaya diri ketika bercerita menggunakan buku cerita, karena harus terpaku oleh teks, dan anak yang tidak mahir membaca enggan untuk bercerita didepan teman-teman dan guru ketika pembelajaran bercerita berlangsung.

Penelitian ini memiliki keterbatasan yaitu hanya terfokus pada anak usia 5-6 tahun, dan memiliki subjek yang sedikit. Diharapkan untuk penelitian kedepan dapat meneliti dengan jumlah subjek yang banyak dan tidak hanya untuk kelompok 5-6 tahun saja namun dibandingkan dengan anak-anak usia 4-5 tahun yang dapat dilihat kemahiran pada anak usia tersebut. Selain itu buku bergambar tanpa kata juga dapat berkembang dikalangan anak-anak usia dini. Supaya dapat melatih anak dalam kemampuan bercerita.

\section{UCAPAN TERIMA KASIH}

Ucapan Terimakasih ini saya berikan kepada Universitas Negeri Yogyakarta.

\section{DAFTAR PUSTAKA}

Carr, M., and W. Lee. (2012). Learning stories: constructing learner identities in Early Education. London: Sage.

Dickinson, D. K., Griffith, J. A., Michnick, R., \& Hirsh-Pasek, K. (2012). How reading books fosters language development around the world. Child Development Research, 2012 http://dx.doi.org/10.1155/2012/602807.

Greenhoot, A., \& Semb, P. A. (2008). Do illustrations enhance preschoolers' memories for stories? Age-related change in the picture facilitation effect. Journal of Experimental Child Psychology, 99(4), 271-287.20Stories.pdf

Hibbin, R. (2016). The psychosocial benefits of oral storytelling in school: developing identity and empathy through narrative, Pastoral Care in Education, 34:4, 218231, DOI: 10.1080/02643944.2016.1225315

Huck, C. S., Hepler, S., \& Hickman, J. (1987). Children's literature in the elementary school. New York: Holt, Rinehart and Winston. 
Isbell, R., T. (2002). Telling and retelling stories learning language and literacy. East Tennessee State University in Johnson City.

Isbell, R., Sobol, J., Lindauer, L., \& Lowrance, A. (2004). The effects of storytelling and story reading on the oral language complexity and story comprehension of young children. East Tennessee State University. Early Childhood Education Journal, Vol. 32, No. 3.

Lenox, M. F. (2002). Storytelling for young children in a multicultural world. Early Childhood Education Journal, Vol. 28, No 2, DOI 1082-3301/00/1200-0097\$18.00/0

Lysaker, J \& Hopper, E. (2015). A Kindergarten's Emergent Strategy Use During Wordless Picture Book Reading. International Literacy Asaction.

Lysaker, J. T., \& Alicea, Z. A. (2016). Theorizing Fiction Reading Engagement During Wordless Book Reading. Elsevier Journal, Linguistic and Education, http://dx.doi.org/10.1016/j.linged.2016.1 1.001

Lysaker, Judith \& Sedberry, Tiffany. (2015). Reading difference: picture book retellings as contexts for exploring personal meanings of race and culture. Literacy UKLA.

Lassley, E. A., Lory, E., \& Haas, L. E. (2017). Visual Literacy, Academic Standards, and Critical Thinking: Using Wordless Picture Books as an Instructional Tool. The California Reader. Vol. 50, No. 2

Lysaker, J. T. (2006). Young Children's Reading of Wordless Picture Books: What's Self Got to Do Whit it?. Sage Publication: Journal of early Childhood Literacy.

Lysaker, J. T., \& Miller, A. (2013). Engaging social imagination: The developmental work of wordless book reading. Journal of Early Childhood Literacy 13(2) 147174. DOI: $10.1177 / 1468798411430425$

Lukens, Rebbeca, J. (2003). A critical handbook of children's literature- $6^{\text {th }}$ ed. Wasley Educational, Publisher Inc. New York: Longman.

Lassley, E. A., Lory, E., \& Haas, L. E. (2017). Visual literacy, academic standards, and critical thinking: using wordless picture books as an instructional tool. The California Reader. Vol. 50, No. 2
Lysaker, J. T. (2006). Young children's reading of wordless picture books: what's self got to do whit it?. Sage Publication: Journal of early Childhood Literacy.

Mitchell, D. (2003). Children's literature an invitation to thre world. Boston: Ablongman.

Roux, A. L. (2015). The production and use of wordless picture books in parent-child reading: an exploratory study within a south African context. Vega school of brand leadership, south Africa.

Ramos, A. M., \& Ramos, R. (2011). Ecoliteracy Through Imagery: A Close Reading of Two Wordless Picture Books. Children's Literature in Education, 325-339, DOI 10.1007/s10583-011-9142-3

Southcott, L. H. (2015). "Learning stories: connecting parents, celebrating success, and valuing children's theories." Voices of Practitioners 34. Accessed November 6, 2015 https://ww w.naeyc.org/files/naeyc/Southcott.Learn ing\%

Sitepu, B. P. (2015). Penulisan Buku Teks Pelajaran. Bandung: Remaja Rosdakarya.

Torr, Jane. (2004). Talking about picture books: The influence of maternal education on four-year-old children's talk with mothers and pre-school teachers. Macquarie University, Australia. Journal of Early Childhood Literacy, vol. 4(2) $181-210$

DOI: $10.1177 / 1468798404044515$

Tower, C. (2002). It's a snake, you guys!: 'The power of text characteristics on children's responses to information books'. Research in the Teaching of English, 37(1), 55-88

Wright, C., Bacigalupa, C., Black, T., \& Burton, M. (2007). Windows into children's thinking: a guide to storytelling and dramatization. Early Childhood Educ J 35:363-369 DOI 10.1007/s10643-0070189-0

Xinyu Yu. (2012). Exploring visual perception and children's interpretations of picture books. Library \& Information Science Research. doi:10.1016/j.lisr.2012.06.004

Zadra, C. 2017. "Wordless picture books beyond school boundaries: visual bridges toward family-school partnerships in education" proceedings at the 
international and interdisciplinary

conference immagini? image and imagination between representation, communication, education and psychology, $\quad 1, \quad 941$. www.mdpi.com/journal/proceedings

Zhang, Q. (2016). Do learning stories tell the whole story of children's learning? A phenomenographic enquiry. Early Years: Taylor \& Francis e-Library. http://dx.doi.org/10.1080/09575146.201

6.1151403 